\title{
The Effect of Evening Primrose (Oenothera biennis) on the Some Biochemical Parameters in Rats with Gentamicin Induced Nephrotoxicity
}

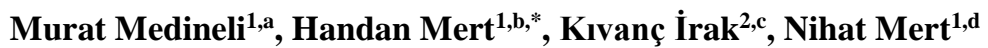 \\ ${ }^{1}$ Department of Biochemistry, Faculty of Veterinary Medicine, Van Yüzüncü Yıl University, 65080 Van, Turkey \\ ${ }^{2}$ Department of Biochemistry, Faculty of Veterinary Medicine, Siirt University, 56100 Siirt, Turkey
}

*Corresponding author

\section{A R T I C L I N F O A B S T R A C T}

\section{Research Article}

In this study, it was aimed to investigate the effect of evening primrose oil (EPO) on some biochemical parameters on nephrotoxicity induced by gentamicin (GM) in rats. The rats used in the study were randomly divided into 4 groups each consisting of 8 rats. The control group, EPO group, GM group and GM+ EPO group. The blood samples were taken 24 hours after the 8-day trial and

Received : 30/09/2020

Accepted : 15/02/2021 kidneys were removed and saved for histopathological and PGE2 analysis. The serum creatinine, BUN, calcitriol, $\mathrm{Ca}, \mathrm{Na}, \mathrm{Cl}, \mathrm{K}$ and $\mathrm{P}$ analyzes were performed via autoanalyser. PGE2 analysis was performed in kidney tissue via ELISA. Histopathological examination of the kidney tissues was performed. The levels of creatinine, BUN and $\mathrm{Cl}$ were significantly decreased and PGE2 and $\mathrm{Ca}$ increased in GM + EPO compared to GM group. The changes in the biochemical parameters

Keywords:

Evening primrose oil Gentamicin examined and the histopathological findings obtained, it can be said that the EPO weakens the

Calcitriol

Nephrotoxicity

PGE2 nephrotoxic damage caused by GM and has the protective effects on the kidney.

muratmedineli@gmail.com kivancirak@hotmail.com http://orcid.org/0000-0002-8029-0284 https://orcid.org/0000-0001-9765-0330 https://orcid.org/0000-0001-9827-7996 https://orcid.org/0000-0001-7185-3316

\section{(c) (i) (3) This work is licensed under Creative Commons Attribution 4.0 International License}

\section{Introduction}

Due to its wide bactericidal spectrum against gentamicin (GM) gram (-) bacteria, its effectiveness against beta-lactam resistant microorganisms and its low cost, its use is very common (Maldonado et al., 2003; Ataman et al., 2018). The most important side effect is nephrotoxicity. Acute kidney failure cases caused by GM are about 10-20\% (Walker and Shah, 1988; Erdem et al., 2012), and therefore their clinical use is limited. Nephrotoxic side effects of aminoglycoside antibiotics have been reported in many experimental animal studies (Ali, 1995; Volpini et al., 2006). Aminoglycosides produce nephrotoxic effects through 3 general mechanisms, such as renal tubular damage, decreased glomerular filtration, and reduced renal blood flow (LopezNovoa et al., 2011). Recent findings suggest that reactive oxygen metabolites play a role in GM nephrotoxicity (Martinez-Salgado et al., 2005). Its elimination is completely due to glomerular filtration in the kidney (Ali, 1995). GM is deposited in lysosomes in proximal tubule cells after filtration through the glomerulus (Ali, 1995;
Mingeot-Leclercq and Tulkens, 1999; Li et al., 2008). The resulting damages; basal membrane erosions, proximal tubular cell swelling and brushed edge loss, tubular atrophy or dilatation, interstitial inflammatory cell infiltration (Volpini et al., 2006) and decreased basolateral membrane folds (Tulkens, 1989).

Evening primrose oil, Oenothera biennis obtained from the seeds of the plant, essential fatty acids (linoleic acid, gamma linoleic acid) and some phenolic compounds containing a high proportion of the product (Kaya, 2013). Evening primrose oil is rich in omega 6 essential fatty acids such as linoleic $(73.5 \%)$ and gamma linolenic acid (GLA) (9\%) (Gao et al., 1995; Bayles and Usatine, 2009). GLA is an effective essential fatty acid and is highly demanded in the field of clinical and pharmacology as it is the precursor of prostaglandin $\mathrm{E}$ and its derivatives (Jennifer and Heywood 2001; Birch et al., 2001). The therapeutic effects of the primrose oil have an indirect effect on the synthesis of eicosanoids (e.g prostaglandins, cytokines, cytokine mediators) directly on immune cells (Vassilopoulos et al., 
1997) as a component of essential fatty acids (Fan and Chapkin, 1998). Evenly taken primrose oil is commonly used in systemic diseases characterized by chronic inflammations such as atopic dermatitis, eczema and rheumatoid arthritis (Bayles and Usatine, 2009).

The aim of this study was to study the effects of the introduction of evening primrose oil in the gentamicininduced nephrotoxic rat on certain biochemical parameters (PGE2, calcitriol, creatinine, BUN, $\mathrm{Ca}, \mathrm{Na}, \mathrm{Cl}, \mathrm{K}, \mathrm{P}$ ) and histopathological changes renal tissue.

\section{Materials and Methods}

\section{Materials and Experimental Conditions}

In the study, 32 female Wistar Albino rats, 250-300 g live weight, which were obtained from Experimental Research Unit of Van Yüzüncü Yıl University Medical Faculty, were used. Before the experiment, adaptation of the rats to the environment for 7 days was achieved. The study was carried out according to the maintenance conditions of laboratory animals (12 hours light: 12 hours dark and $24 \pm 3^{\circ} \mathrm{C}$ ) in experimental applications. Standard experimental rat feed (pellet feed) and drinking water ad libitum were given to the rats during experimental applications.

The study was carried out in accordance with the code of ethics, with the approval of the Local Ethics Committee of the Animal Experiments of Van Yüzüncü Yıl University $(24 / 11 / 2016,2016 / 11)$.

\section{Experimental Procedure}

Female Wistar Albino rats $(n=32)$ were randomly divided into four groups that each of has 8 rats:

Control group: Physiological saline was given for 8 days (i.p).

Primrose oil group (EPO): The animals were given a dose of $0.1 \mathrm{ml} /$ rat / day with a primrose oil gavage for 8 days (Kaya, 2013).

Gentamycin group (GM): Gentamicin $80 \mathrm{mg} / \mathrm{kg} /$ day / i.p was given for 8 days.

Gentamycin+Evening primrose oil group (GM+EPO): The animals were given gentamicin $80 \mathrm{mg} / \mathrm{kg} /$ day / i.p and a dose of $0.1 \mathrm{ml} /$ rat / day with primrose oil gavage for 8 days.

\section{Biochemical Analysis}

After experimental applications (day 9), all rats were given $90 \mathrm{mg} / \mathrm{kg}$ ketamine i.p and the blood samples were taken directly from the heart. Blood samples were taken into the tubes for biochemical parameters to be studied. Sera was removed by centrifugation and stored at $-18^{\circ} \mathrm{C}$ until analysis. Animals were sacrificed and both kidneys were removed immediately for the PGE2 analysis and histopathological examinations.

\section{Analysis in Serum}

Serum creatinine (Roche/Hitachi, Kit No:694563), BUN (Roche/Hitachi, Kit No:693369), calcitriol (Roche/Hitachi, Kit No: 05894913), Na (Roche/Hitachi, Kit No: 693473), Cl (Roche/Hitachi, Kit No: 699020), K (Roche/Hitachi, Kit No:696550) and P (Roche/Hitachi, Kit No: 697630) analyses were performed in the Roche Modular P 800 auto analyser.

\section{PGE2 Analysis of Kidney Tissue}

PGE2 levels of kidney tissue were measured using ELISA commercial kits (ABCAM). For this purpose, all kidney tissue was taken and weighed and homogenized in Cold RIPA lysis buffer containing 1\% PMSF protease inhibitor. The lysate was centrifuged at $4{ }^{\circ} \mathrm{C}$ for 10 minutes at $12,000 \times \mathrm{g}$. The obtained supernatant was used in ELISA analysis (Niu et al., 2014).

\section{Histopathological Examination}

Kidney tissue preparations prepared with $10 \%$ formaldehyde for histopathological investigations were stained with Van Gieson and Mallory's staining techniques and examined under a microscope.

\section{Statistical Analysis}

Descriptive statistics for the characteristics emphasized are expressed as Mean and Standard Deviation. Kruskal Wallis analysis was performed to compare the groups. Dunnett test was used to determine different groups. Statistical significance level was taken as $5 \%$ in the calculations and SPSS statistical package program was used.

\section{Results}

\section{Biochemical Findings}

The mean levels of PGE2 in renal tissues, and levels of serum creatinine, BUN, calcitriol, calcium, sodium, chloride, potassium, phosphorus are presented in Table 1.

The levels of creatinine $(\mathrm{P}<0.001)$, BUN $(\mathrm{P}<0.001)$ and $\mathrm{Cl} \quad(\mathrm{P}<0.5)$ were significantly decreased and $\mathrm{PGE} 2$ $(\mathrm{P}<0.01)$ and $\mathrm{Ca}(\mathrm{P}<0.01)$ increased in $\mathrm{GM}+\mathrm{EPO}$ compared to GM group.

Table 1. Mean values of some biochemical parameters of control, EPO, GM, GM + EPO group rats.

\begin{tabular}{|c|c|c|c|c|c|}
\hline Parameters & $\begin{array}{c}\text { Control } \\
\mathrm{X} \pm \mathrm{Sx}\end{array}$ & $\begin{array}{c}\mathrm{EPO} \\
\mathrm{X} \pm \mathrm{Sx}\end{array}$ & $\begin{array}{c}\mathrm{GM} \\
\mathrm{X} \pm \mathrm{Sx}\end{array}$ & $\begin{array}{c}\mathrm{GM}+\mathrm{EPO} \\
\mathrm{X} \pm \mathrm{Sx}\end{array}$ & $\mathrm{p}$ \\
\hline Creatinine (mg/dl) & $0.34 \pm 0.05^{\mathrm{b}}$ & $0.32 \pm 0.03^{\mathrm{b}}$ & $0.91 \pm 0.07^{\mathrm{a}}$ & $0.34 \pm 0.03^{\mathrm{b}}$ & 0.001 \\
\hline $\mathrm{BUN}(\mathrm{mg} / \mathrm{dl})$ & $18.38 \pm 1.06^{\mathrm{b}}$ & $17.88 \pm 1.73^{\mathrm{bc}}$ & $27.63 \pm 1.06^{\mathrm{a}}$ & $16.50 \pm 2.00^{\mathrm{c}}$ & 0.001 \\
\hline PGE2 (pg/g wet tissue) & $264.40 \pm 24.99^{\mathrm{a}}$ & $282.10 \pm 33.45^{\mathrm{a}}$ & $159.30 \pm 35.40^{c}$ & $215.40 \pm 28.70^{\mathrm{b}}$ & 0.01 \\
\hline Calcitriol (ng/ml) & $33.10 \pm 9.89^{\mathrm{a}}$ & $30.66 \pm 5.00^{\mathrm{a}}$ & $26.33 \pm 3.37^{\mathrm{a}}$ & $28.63 \pm 10.17^{\mathrm{a}}$ & 0.295 \\
\hline Calcium (mg/dl) & $9.30 \pm 0.41^{\mathrm{ab}}$ & $9.24 \pm 0.23^{\mathrm{ab}}$ & $9.03 \pm 0.12^{\mathrm{b}}$ & $9.54 \pm 0.37^{\mathrm{a}}$ & 0.008 \\
\hline Sodium (nmol/L) & $135.75 \pm 1.98^{\mathrm{a}}$ & $136.00 \pm 1.07^{\mathrm{a}}$ & $135.88 \pm 0.83^{\mathrm{a}}$ & $134.75 \pm 1.28$ & 0.256 \\
\hline Chlorine (nmol/L) & $96.09 \pm 3.18^{\mathrm{b}}$ & $98.91 \pm 1.34^{\mathrm{a}}$ & $100.40 \pm 1.33^{\mathrm{a}}$ & $96.23 \pm 2.04^{\mathrm{b}}$ & 0.02 \\
\hline Potassium (nmol/L) & $4.91 \pm 0.36^{\mathrm{a}}$ & $4.57 \pm 0.25^{\mathrm{b}}$ & $4.99 \pm 0.32^{\mathrm{a}}$ & $4.88 \pm 0.22^{\mathrm{a}}$ & 0.039 \\
\hline Phosphorus (mg/dl) & $7.23 \pm 0.87^{\mathrm{a}}$ & $7.07 \pm 0.52^{\mathrm{a}}$ & $7.15 \pm 0.76$ & $7.39 \pm 0.99^{\mathrm{a}}$ & 0.850 \\
\hline
\end{tabular}




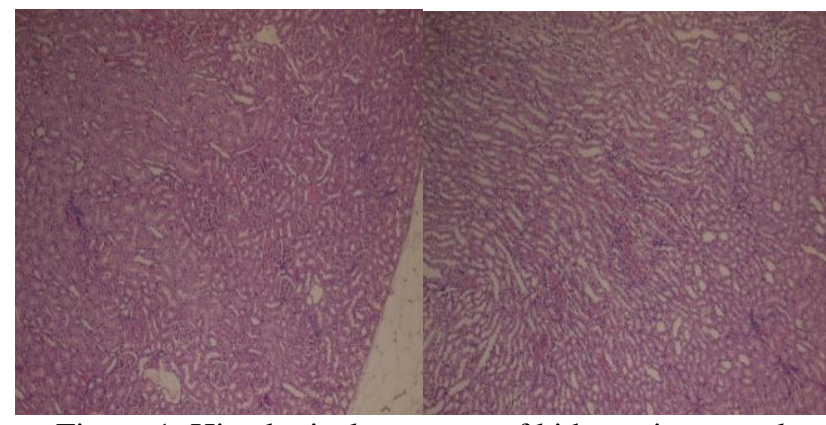

Figure 1. Histological structure of kidneys in control group

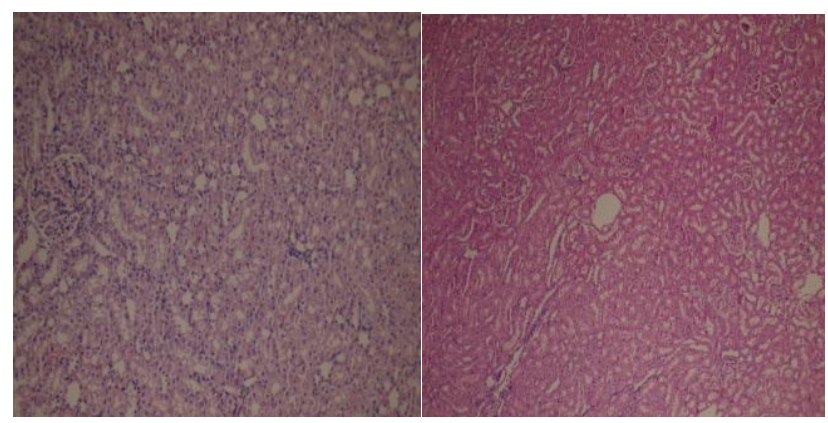

Figure 2. Histological structure of kidneys of rats in the EPO group

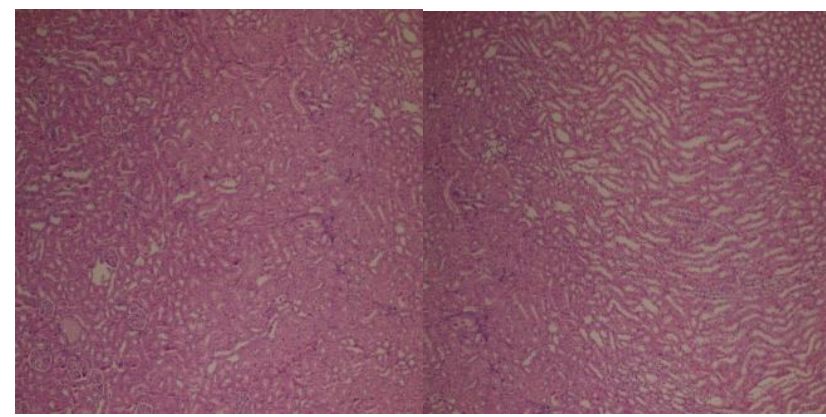

Figure 3. Histological structure of kidneys in rats in GM group

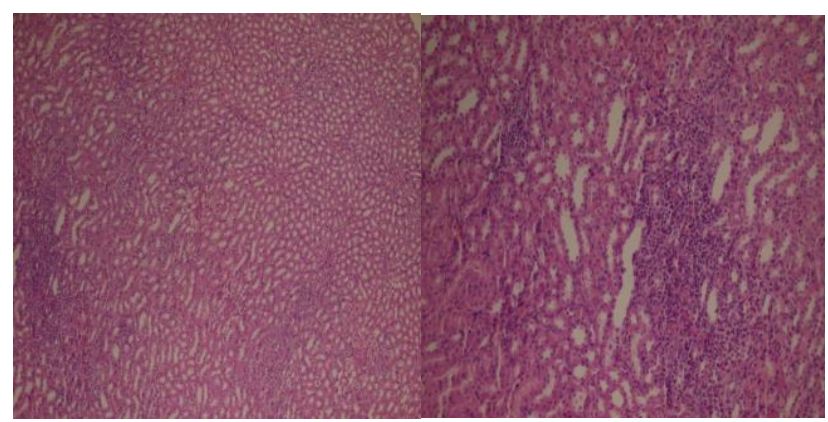

Figure 4. Histological structure of kidneys of GM + EPO group

\section{Histopathological Findings}

Histopathological examination of the kidneys; with the exception of slight interstitial congestion in the control group, the kidneys were normal (Figure 1).

The kidneys of the primrose oil group rats were normal with the exception of light interstitial congestion as in the control group (Figure 2).

In the kidneys of the gentamicin group, an increase in mononuclear cells and severe tubular damage were found in the interstitial region. Glomeruli could not be preserved and a significant increase in toxicity occurred (Figure 3).

In the kidneys of the GM + primrose oil group, the increase in the number of mononuclear cells in the interstitial zone was moderate. Tubular damage was present but moderately reduced. A decrease in renal toxicity was observed (Figure 4).

\section{Discussion}

Although gentamicin, an aminoglycoside, is an antibiotic commonly used in gram (-) bacterial infections, its administration is limited due to nephrotoxic side effects and oxidative damage leading to acute renal failure. Approximately $10-25 \%$ of all patients using gentamicin have nephrotoxicity (Lopez-Novoa et al., 2011). Creatinine and BUN levels are frequently used as a marker of renal function. When renal dysfunction occurs, kidneys' ability to filter out creatinine decreases and serum creatinine levels increase (He et al., 2009). Serum creatinine concentration is much more important than BUN in the early phase of renal diseases (Hozayen et al., 2011). On the other hand, after a significant renal parenchymal injury, BUN begins to rise (Erdem et al., 2000). It was reported that nephrotoxic effect of cyclosporine was partially inhibited when the animals fed with EPO containing 9\% gamma linolenic acid or fish oil supplemented with 5.6\% eicosapentaenoic acid (Morphake et al., 1994).

In this study, serum creatinine and BUN levels of the GM group were found to be significantly higher than the control group $(\mathrm{P}<0.001)$. The creatinine and BUN levels of the group given GM and additional primrose oil decreased significantly compared to the GM group $(\mathrm{P}<0.001)$ and it has been found to be approaching to the values of control group. According to the decrease in these parameters which give information about kidney function, it can be said that evening primrose oil prevents nephrotoxicity caused by gentamine and has a renoprotective effect. Gao et al. (1995) reported that serum and urine creatinine levels decreased by $\mathrm{P}<0.05$ compared to the pre-treatment period by giving primrose oil to the patients with chronic renal failure.

Aminoglycosides cause a vasoconstriction effect effect in the kidney with thromboxane B2. In particular, they make direct cellular toxicity in the proximal tubule, which absorbs the drugs and stores them in the lysosome. Tubular necrosis, tubular atrophy, intertubular myoloid bodies and interstitial nephritis are shaped (Cuzzocrea et al., 2002; Maldonado et al., 2003).

Yilmaz et al. (2018) reported that histopathological examination of kidney tissues of rats treated with gentamicin showed atrophy and signs of acute tubular necrosis. It has been determined that the cytoplasm of the cells laying the tubule epithelium increases the acidophilus in certain areas and shows degenerative changes. It was found that epithelial cells laying the tubules were discharged, capsular space was irregular in renal bodies and expanded in places.

In this study, mononuclear cell increase and severe tubular damage were observed in the interstitial area of kidneys of rats in the GM group. It was found that glomeruli could not be protected and there was a significant increase in toxicity. With the additional 
primrose oil (GM + EPO group), the increase in mononuclear cells in the interstitial area in the kidneys of the rats is moderate. Tubular damage is present but moderately reduced. A decrease in renal toxicity was observed.

Prostaglandins are important mediators of human physiology and diseases. Prostaglandins are derived from the metabolism of arahidonic acid by cyclooxygenase (Vane et al., 2005). Renal prostaglandins interfere with the three general areas of renal function a by playing a role in the control of renin secretion, regulation of vascular tone and control of tubular transport functions (Lopez et al., 2003). As a result of worsening of renal status, prostaglandins perform these functions to protect renal blood flow and glomerular filtration rate (Yared et al., 1985).

Different cells along the nephron can synthesize PGE2 (Farman et al., 1987). Glomerular cells, including epithelial, endothelial or mesagenic cells, are capable of producing both PGF2 and PGI2 and PGE2 (Dunn, 1989). Kidney tubule cells are the site of synthesis of renal prostaglandins, particularly renal medulla, and PGE2 is the major synthesized prostanoid (Farman et al., 1987).

The renal vasodilator synthesis of prostaglandins is not very effective under normal physiological conditions. However, in patients with hypertension, congestive heart failure, cirrhosis, glomerular disease, and renal failure, the synthesis of vasodilator renal prostaglandins is gaining importance (Canayakın, 2014). Again, prostaglandins have been shown to protect the kidneys against direct ischemic and toxic damage (Paller et al., 1992). PGE2 has been reported to exert a vasodilatory effect on the kidney. These results have a specific role in maintaining normal renal blood flow and GFR in the development of aminoglycoside nephrotoxicity (Assael et al., 1985). Werb et al. (1978) produced acute renal failure with glycerol and different doses of PGE2, were administered intravenously and indicated that PGE2 had a protective effect. They linked this nephrotoxicity correction of prostaglandins by glycerol to both the vasoditator effect of PGE2 and its effect on the increase in glomerular capillary permeability.

It has been reported that cardiovascular risk factors are reduced and renal functions are stabilized by giving gamma linolenic acid to the elderly for three months (Hornych et al., 2002). They stated that epogam treatment increases the biosynthesis of PGE2, which has vasodilator effect on vascular walls and decreases elevated blood pressure from renal prostaglandins.

Bi et al. (1992) reported that when Oenothera biennis $L$. was given orally in chronic renal failure, PGE1 and PGE2 levels were increased in both renal cortex and medulla, Oenothera biennis L. had a positive effect on kidney and could be used as a conservative treatment for chronic renal failure.

In this study, it was found that the level of renal PGE2 in the GM group decreased significantly compared to other groups. Papanikolaou et al. (1992) and Lopez-Novoa et al. (2011) reported that gentamicin blocked the vasodilator synthesis of prostaglandins. In the present study, kidney PGE2 level increased with the administration of EPO, containing gamma linolenic acid and linoleic acid as the precursors of arahidonic acid, to gentamicin group. The enhanced synthesis of PGE2 effective for vasodilators has reduced the nephrotoxic effect caused by GM. Higa et al. (1985) reported that prostaglandins protected against aminoglycoside toxicity. Gao et al. (1995) pointed out that primrose oil improves intrarenal circulation by increasing the efficacy of keto PGF1 alpha vasodilator.

Vitamin D is a steroid-based prohormone produced in the skin under the influence of the sun's rays. Calcitriol $(1,25(\mathrm{OH}) 2 \mathrm{D})$, a form of physiologically active vitamin $\mathrm{D}$, appears in the mitochondria of the proximal tubules of the kidneys by advanced hydroxylation of 25-OH D in 1,25 $(\mathrm{OH}) 2 \mathrm{D}$. Vitamin D and 1,25 $(\mathrm{OH}) 2 \mathrm{D}$ are related to calcium balance and are regulated by serum calcium, phosphorus and parathyroid hormone (PTH) levels (Yavuz et al., 2014). 1,25 (OH) $2 \mathrm{D}$ allows the active transport of $\mathrm{Ca}$ in the gastrointestinal tract. It binds to cytosolic 1.25 $(\mathrm{OH}) 2 \mathrm{D}$ nuclear receptors and stimulates the production of calcium binding proteins and mRNAs for the synthesis of enzymes involved in calcium transport.

Vitamin D provides not only calcium homeostasis, but also anti-inflammatory, pro-apoptotic and immunomodulatory properties. Low vitamin D levels would increase cancer incidence and cardiovascular mortality and are associated with autoimmune diseases such as diabetes and multiple sclerosis (Yavuz et al., 2014). Among the causes of vitamin D deficiency, insufficient diet vitamin $\mathrm{D}$, diseases leading to disorders of fat absorption, deterioration of hydroxylation will lead to the the formation of $25 \mathrm{OH} \mathrm{D}$ in the liver, again the deterioration of hydroxylation will lead to formation of calcitriol in the kidneys, insensitivity of target organs to vitamin D metabolites (vitamin D-resistant hereditary rickets) (Kennel et al., 2010).

The renin-angiotensin system is the obligatory mediator of kidney damage in the kidneys (Ender et al., 2013). 1,25 (OH) 2D is a negative regulatory effect on the renin-angiotensin system by suppressing the expression of renin. Preservation of serum $1,25(\mathrm{OH}) 2 \mathrm{D}$ levels is necessary not only for calcium homeostasis, but also for homeostasis of electrolytes volume and blood pressure $(\mathrm{Li}$ et al., 2002). 1, $25(\mathrm{OH}) 2 \mathrm{D}$ treatment reduces blood pressure, plasma renin activity and angiotensin II level in patients with hyperparathyroidism (Kimura et al., 1999; Park et al., 1999).

PGE2 increases the synthesis of 25-hydroxy-vitamin D-1 $\alpha$-hydroxylase and calcitriol. Hypercalciuria then occurs with Bartter's syndrome, hyperprostaglandin E syndrome and EGP infusion. Idiopathic hypercalciuria has been shown to increase PGE2-like activity, which is associated with the amount of $\mathrm{Ca}$ excreted in the urine and serum calcitriol levels. PGE2 may play a role in hypercalciuria by increasing calcitriol synthesis (Buck, 1990; Hasanoglu et al., 1997; Soylu, 2008). It is suggested that indomethacin, an inhibitor of prostaglandin synthesis, inhibits hypercalciuria and that these effects of cyclooxygenase inhibitors decrease the excretion of $\mathrm{Na}$ and $\mathrm{Ca}$ in the ascending limb of Henle loop (Buck, 1990).

Stojiljkovic et al. (2012) showed that $\mathrm{Ca}^{2+}$ which was given orally with GM during the treatment, significantly reduced morphological and functional renal changes in GM-induced nephrotoxicity, and that $\mathrm{Ca}^{2+}$ had a healing effect on GM's nephrotoxicity. High-dose GM caused damage, but $\mathrm{Ca}^{2+}$ loading increased the distribution of ions in the kidney and prevented GM binding to brush border 
membranes. This protective mechanism of Ca may be the competitive substitution of $\mathrm{Ca}^{2+}$ with anionic phospholipids in plasma and organelle membranes. Another possibility is that competently increasing $\mathrm{Ca}^{2+}$ inhibits the primary lesion with anionic phospholipid binding. The final possibility is that $\mathrm{Ca}^{2+}$ may prevent critical cellular disturbances generated by GM in renal tubular cells rather than cell surface.

In this study, although the lowest calcitriol was obtained in the GM group, no statistically significant difference was found between the groups. It was observed that the level of calcitriol increased by giving EPO to the GM group. Serum calcium was the lowest in the GM group and the highest in the GM + EPO group. It has been reported that PGE2 increases the synthesis of 25-hydroxyvitamin D-1 $\alpha$-hydroxylase and calcitriol (Buck, 1990; Hasanoğlu et al., 1997). As a result, the calcitriol level can be increased in parallel with the increase in PGE2 in the $\mathrm{GM}+\mathrm{EPO}$ group. Some studies report that $\mathrm{Ca}$ has a curative effect on the nephrotoxicity of GM and that it prevents the binding of GM to brush border membranes (Stojiljkovic et al., 2012). Ca administration by diet delayed nephrotoxicity and decreased severity (Quarum et al., 1984). In this study, it can say that elevation of serum $\mathrm{Ca}$ is elevated parallel to that of calcitriol and that $\mathrm{Ca}$ excretion is regulated according to the needs of the organism.

The kidneys play a very important role in regulating the balance of liquids and electrolytes in the body. Thus, when renal failure develops, fluid balance disorders, electrolytes and acidic bases are inevitable. Renal diseases are frequently associated with hypervolemia, hyperkalemia, hyponatremia, hyperphosphatemia, hypocalcemia, hypermagnaemia, and metabolic acidosis (Mert, 1996). In general, the severity of these electrolyte disturbances reflects the degree of renal impairment and the catabolic state of the patient. In renal failure, oliguric states are mainly associated with hyponatraemia and polyuric states are hypernatremia (Caliskan anf Yildiz, 2010).

Stojiljkovic et al. (2012) showed that the potassium level of the gentamicin group decreased with respect to the controls $(\mathrm{P}<0.01)$, and Maden and Aslan (1999) reported decreases in the serum $\mathrm{Na}$ level of the gentamicin group compared to the control group $(\mathrm{P}<0.01)$, and increases in serum $\mathrm{P}$ and $\mathrm{K}$ levels $(\mathrm{P}<0.01)$. Polzin Osborne, \& O'Brien (1989), found increases in serum $K$ and $P$ levels in dogs with acute renal failure cases, also Bayly (1991) reported that hyperphosphatemia indicates renal failure in small animals. In this study, serum $\mathrm{Na}, \mathrm{Cl}, \mathrm{K}$ and $\mathrm{P}$ levels were examined. Serum Na and $\mathrm{P}$ levels were not significantly different between groups. Although changes in the distribution of renal electrolytes have been introduced with the administration of gentamicin to animals, changes in aminoglycosides in plasma electrolytes have sometimes been observed. This may be due to the presence of large amounts of electrolytes in standard feeds for laboratory animals or the absence of other factors that predispose to electrolyte imbalance (Bach and Lock, 1987). In the current study, serum $\mathrm{Cl}$ and $\mathrm{K}$ levels were found to be highest in the GM group. In addition to GM, it was observed that both $\mathrm{Cl}$ and $\mathrm{K}$ levels decreased with the introduction of evening primrose oil $(\mathrm{P}<0.05)$.
Noorani et al. (2010) showed that serum Na level changes in rats with nephrotoxicity were insignificant and potassium and chlorine levels were higher than control group $(\mathrm{P}<0.05)$.

\section{Conclusion}

This study will shed light on the studies to be carried out as it is the first study to show the effect of EPO on gentamicin-induced nephrotoxicity. In particular, the administration of EPO containing gamma-linolenic acid and linoleic acid, precursors of arahidonic acid to the GM group, increased the synthesis of vasodilatory PGE2 in renal tissue and reduced the nephrotoxic effect caused by GM. In addition, it has been observed that the level of $\mathrm{Ca}$ is higher in the GM + EPO group than in the GM group, and it is a second condition that reduces the severity of nephroxicity. As a result, changes in the biochemical parameters and histopathological findings revealed that the evening primrose oil attenuated the nephrotoxic damage caused by GM and had a kidney protective feature.

\section{Acknowledgements}

This research was supported by the Van YYU Directory of Scientific Research Project as (2015- SBEYL036) Project number.

This manuscript is summarized from master's thesis of Murat Medineli. The study has been orally presented and published as abstract in the ISPEC 3rd International Conference on Agriculture, Animal Husbandry and Rural Development 20-22 December 2019 Van, TURKEY.

\section{Conflicts of Interest}

Authors have no conflict of interest.

\section{References}

Ali BH. 1995. Gentamicin nephrotoxicity in humans and animals: some recent research. General Pharmacology, 26: 1477-1487. doi: 10.1016/0306-3623(95)00049-6

Assael BM, Chiabrando C, Gagliardi L, Noseda A, Bamonte F, Salmona M. 1985. Prostaglandins and aminoglycoside nephrotoxicity. Toxicology and Applied Pharmacology, 78: 386-394. doi:

Ataman N, Mert H, Yildirim S, Mert N. 2018. The effect of fucoidan on changes of some biochemical parameters in nephrotoxicity induced by gentamicin in rats. Ankara Üniversitesi Veteriner Fakültesi Dergisi, 65: 9-14. doi: 10.1501/Vetfak_0000002821

Bach PH, Lock EA. 1987. Nephrotoxicity in the Experimental and Clinical Situation, (Part 2), Martinus Nijhoff Publishers, ISBN 978-94-009-3371-2.

Bayles B, Usatine R. 2009. Evening primrose oil. American Family Physician, 80: 1405-1408.

Bayly W. 1991. A practitioner's approach to the diagnosis and treatment of renal failure in horses. Veterinary Medicine, 86: 632-639.

Bi ZQ, Bo YH, Duan JH. 1992. Treatment of chronic renal failure with Oenothera beinnis L. in rats with subtotal nephrectomy. Zhonghua Nei Ke Za Zhi, 31: 7-10, 59.

Birch AE, Fenner GP, Watkins R, Boyd LC. 2001. Antioxidant properties of evening primrose seed extracts. Journal of Agricultural and Food Chemistry, 49: 4502-4507. doi:10.1021/jf010542f 
Buck AC. 1990. The renal handling of calcium. Wickham JEA, Buck AC. Renal tract stone 1st ed. Churchill: Livingtone, Edinburg, 165-182.

Caliskan Y, Yildiz A. 2010. Electrolyte Disturbances in Renal Failure. Türkiye Klinikleri Nefroloji, 3: 44-49.

Canayakın D. 2014. Investigation of the Nigella sativa L. Ethanol extracts induced by paracetamol on acute kidney toxicity in rats. MSc Thesis, Atatürk University, Erzurum, Turkey.

Cuzzocrea S, Mazzon E, Dugo L, Serraino I, Di Paola R, Britti D, Sarro AD, Pierpaoli S, Caputi A, Masini E, Salvemini D. 2002. A role for superoxide in gentamicin-mediated nephropathy in rats. European Journal of Pharmacology, 450: 67-76. doi:10.1016/s0014-2999(02)01749-1

Dunn MJ. 1989. Glomerular eicosanoids and diabetes mellitus. Journal of Laboratory and Clinical Medicine, 113: 659-661.

Ender H, Garip A, Camyar A, Ilgun S, Özışık M, Tuna S, Olukman M, Ozdemir ZN, Sozmen EY, Sen S, Akcicek F, Duman S. 2013. The effects of vitamin D on gentamicininduced acute kidney injury in experimental rat model. International Journal of Endocrinology, 2013: 313528. doi: $10.1155 / 2013 / 313528$

Erdem A, Gundogan NU, Usubutun A. 2000. The protective effect of taurine against gentamicin-induced acute tubular necrosis in rats. Nephrology Dialysis Transplantation, 15: 1175- 1182. doi: 10.1093/ndt/15.8.1175

Erdem E, Özdemir A, Kaya C, Karataş A, Cengiz K. 2012. Serum Uric Acid Levels in Chronic Kidney Disease. Frrat Medical Journal, 17: 23-27.

Fan YY, Chapkin RS. 1998. Importance of dietary gammalinolenic acid in human health and nutrition. The Journal of Nutrition, 128: 1411-1414. doi: 10.1093/jn/128.9.1411

Farman N, Pradelles P, Bonvalet JP. 1987. PGE2, PGF2 alpha, 6 keto-PGF1 alpha, and TxB2 synthesis along the rabbit nephron. The American journal of physiology, 252: F53-59. doi:10.1152/ajprenal.1987.252.1.F53

Gao H, Yu Z, Qiu X, Tian S, Guo G, Li W, Hu X, Liu L, Li H, He H. 1995. Effects of oenethera biennis oil on plasma lipid, thromboxane A2 and angiotensin II of chronic renal insufficiency. Chinese Journal of Integrated Traditional and Western Medicine, 1: 272 - 274.

Hasanoğlu A, Ercan ZS, Buyan N, Memioglu N, Hasanoğlu E. 1997. Parathormone, 1,25 dihydroxyvitamin D and prostaglandin E2 correlation in children with idiopathic hypercalciuria. Prostaglandins, Leukotrienes and Essential Fatty Acids, 56: 235-237. doi:10.1016/s09523278(97)90541-x

He L, Shen P, Fu Q, Li J, Dan M, Wang X, Jia W. 2009. Nephroprotective effect of Kangqianling decoction on chronic renal failure rats. Journal of Ethnopharmacology, 122: 367-373. doi: 10.1016/j.jep.2008.12.018

Higa EM, Schor N, Boim MA, Ajzen H, Ramos OL. 1985. Role of the prostaglandin and kallikrein-kinin systems in aminoglycoside-induced acute renal failure. Brazilian Journal of Medical and Biological Research, 18: 355-365.

Hornych A, Oravec S, Girault F, Forette B, Horrobin DF. 2002. The effect of gamma-linolenic acid on plasma and membrane lipids and renal prostaglandin synthesis in older subjects. Bratislavské Lekárske Listy, 103: 101-107.

Hozayen W, Bastawy M, Elshafeey H. 2011. Effects of aqueous purslane (Portulaca Oleracea) extract and fish oil on gentamicin nephrotoxicity in albino rats. Nature and Science, 9: 47-62.

Jennifer MMW, Heywood JS. 2001. Pollination limitation to reproductive success in the missouri evening primrose, Oenothera Macrocarpa (Onagraceae). American Journal of Botany, 88(9): 1615-1622.

Kaya Z, Eraslan G. 2013. The Effects of Evening Primrose Oil on Arsenic-Induced Oxidative Stress in Rats. Toxicological and Environmental Chemistry, 95: 1416-1423. doi:10.1080/02772248.2013.866237
Kennel KA, Drake MT, Hurley DL. 2010. Vitamin D deficiency in adults: when to test and how to treat. Mayo Clinic Proceedings, 85: 752-758. doi: 10.4065/mcp.2010.0138

Kimura Y, Kawamura M, Owada M, Oshima T, Murooka M, Fujiwara T, Hiramori K. 1999. Effectiveness of 1,25 dihydroxyvitamin D supplementation on blood pressure reduction in apseudohypoparathyroidism patient with high renin activity. Internal medicine, 38: 31-35. doi:10.2169/internalmedicine.38.31

Li M, Maderdrut JL, Lertora JJ, Arimura A, Batuman V. 2008. Renoprotection by pituitary adenylate cyclase-activating polypeptide in multiple myeloma and other kidney diseases. Regulatory peptides, 145: 24-32. doi:10.1016/j.regpep. 2007.09.012

Li YC, Kong J, Wei M, Chen ZF, Liu SQ, Cao LP. 2002. 1, $25-$ Dihydroxyvitamin D (3) is a negative endocrine regulator of the renin-angiotensin system. The Journal of Clinical Investigation, 110: 229-238. doi:10.1172/JCI15219

Lopez R, Llinas MT, Roig F, Salazar FJ. 2003. Role of nitric oxide and cyclooxygenase- 2 in regulating the renal hemodynamic response to norepinephrine. American Journal of Physiology. Regulatory, İntegrative and Comparative Physiology, 284: 488-493. doi:10.1152/ajpregu.00449.2002

Lopez-Novoa JM, Quiros Y, Vicente L, Morales AI, LopezHernandez FJ. 2011. New insights into the mechanism of aminoglycoside nephrotoxicity: an integrative point of view. Kidney international, 79: 33-45. doi: 10.1038/ki.2010.337

Maden M, Aslan V. 1999. The Importance of Urinary Enzyme Activities in Dogs with Experimentally Induced Gentamicin Nephrotoxicity. The Turkish Journal of Veterinary and Animal Sciences, 23: 29-42.

Maldonado PD, Barrera D, Rivero I, Mata R, Medina-Campos ON, Hernandez-Pando R, Chaverrí JP. 2003. Antioxidant Sallylcysteine prevents gentamicin-induced oxidative stress and renal damage. Free Radical Biology and Medicine, 35(3): 317324. doi: 10.1016/s0891-5849(03)00312-5

Martinez-Salgado C, Rodriguez-Barbero A, Eleno N, LópezNovoa JM 2005. Gentamicin induces Jun-AP1 expression and JNK activation in renal glomeruli and cultured mesangial cells. Life Science, 77: 2285-2298. doi:10.1016/ j.lfs.2005.02.021

Mert N. 1996. Veteriner Klinik Biyokimya, UÜ Güçlendirme Vakfi, Yayın No: 12, Bursa, ISBN:975-564-050-9.

Mingeot-Leclercq MP, Tulkens PM. 1999. Aminoglycosides: nephrotoxicity. Antimicrobial Agents and Chemotherapy, 43: 1003-1012. doi:10.1128/AAC.43.5.1003

Moody-Weis JM, Heywood JS. 2001. Pollination limitation to reproductive success in the missouri evening primrose, Oenothera Macrocarpa (Onagraceae). American Journal of Botany, 88: 1615-1622. doi:10.2307/3558406

Morphake P, Bariety J, Darlametsos I, Tsipas G, Gkikas G, Hornysh A, Papanikolaoua N. 1994. Alteration of cyclosporine (CsA)-induced nephrotoxicity by gamma linolenic acid (GLA) and eicosapentaenoic acid (EPA) in Wistar rats. Prostaglandins, Leukotrienes and Essential Fatty Acids, 50: 29-35. doi: 10.1016/0952-3278(94)90102-3

Niu X, Mu Q, Li W, Yao H, Li H, Li Y, Hu H, Huang H. 2014. Protective effects of esculentic acid against endotoxic shock in Kunming mice. International immunopharmacology, 23: 229235. doi: 10.1016/j.intimp.2014.08.022

Noorani AA, Grupra K, Bhadada K, Kale MK. 2010. Protective effect of methanolic leaf extract of Caesalpinia Bonduc (L.) on gentamicin-induced hepatotoxicity and nephrotoxicity in rats. Iranian Journal of Pharmacology and Therapeutics, 1: 21-25.

NTP. 2009. Chemical information review document for evening primrose oil (Oenotherabiensis L) CAS No 90028-66-3 2009; 1-37, Available from: https://ntp.niehs.nih.gov/ntp/ noms/support_docs/evening_primrose_nov2009.pdf.

Paller MS, Manivel JC. 1992. Prostaglandins protect kidneys against ischemic and toxic injury by a cellular effect. Kidney International, 42:1345-1354. doi:10.1038/ki.1992.426 
Papanikolaou N, Peros G, Morphake P, Gkikas G, Maraghianne D, Tsipas G, Kostopoulos K Arambatze C, Gkika EL Bariety J. 1992. Does gentamicin induce acute renal failure by increasing renal TXA2 synthesis in rats? Prostaglandins, Leukotrienes and Essential Fatty Acids, 45:131-136 doi:10.1016/0952-3278(92)90229-c

Park CW, Oh YS, Shin YS, Kim CM, Kim YS, Kim SY, Choi EJ, Chang YS, Bang BK 1999. Intravenous calcitriol regresses myocardial hypertrophy in hemodialysis patients with secondary hyperparathyroidism. American Journal of Kidney Diseases, 33: 73-81. doi:10.1016/s0272-6386(99)70260-x

Polzin D, Osborne C, O'Brien T. 1989. Diseases of The Kidneys and Ureters. In Textbook of Veterinary Internal MedicineDiseases of The Dog and Cat, Third Edition, W.B. Saunders Company, Philadelphia, Ad SJ Ettinger.

Quarum ML, Houghton DC, Gilbert ND, McCarron DA, Bennett WM. 1984. Increasing dietary calcium moderates experimental gentamicin nephrotoxicity. The Journal of Laboratory and Clinical Medicine. 103: 104-114.

Soylu GS. 2008. Investigation of urinary calcium level in children with nephrotic syndrome and bronchial hyperreactivity. Medical Faculty Thesis, Adnan Menderes University, Aydın, Turkey.

Stojiljkovic N, Stoiljkovic M, Mihailovic D, Randjelovic P, Ilic S, Gocmanac-Ignjatovic M, Veljkovic M. 2012. Beneficial effects of calcium oral coadministration in gentamicininduced nephrotoxicity in rats. Renal Failure, 34: 622-627. doi: 10.3109/0886022X.2012.664809

Tulkens PM. 1989. Nephrotoxicity of aminoglycoside antibiotics. Toxicology Letters, 46: 107-123. doi:10.1016/03784274(89)90121-5

Vane JR, Bakhle YS, Botting RM. 1998. Cyclooxygenases 1 and 2. Annual review of pharmacology and toxicology, 38: 97120. doi:10.1146/annurev.pharmtox.38.1.97
Vassilopoulos D, Zurier RB, Rossetti RG, Tsokos GC. 1997. Gammalinolenic acid and dihomogammalinolenic acid suppress the CD3-mediated signal transduction pathway in human T cells. Clinical Immunology and Immunopathology, 83: 237-244. doi: 10.1006/clin.1997.4343

Volpini RA, Balbi AP, Costa RS, Coimbra TM. 2006. Increased expression of $\mathrm{p} 38$ mitogen-activated protein kinase is related to the acute renal lesions induced by gentamicin. Brazilian Journal of Medical and Biological Research, 39: 817-823. doi: 10.1590/s0100-879x2006000600016

Walker PD, Shah SV. 1988. Evidence suggesting a role for hydroxyl radical in gentamicin-induced acute renal failure in rats. The Journal of Clinical İnvestigation, 81: 334-341. doi: 10.1172/JCI113325

Werb R, Clark WF, Lindsay RM, Jones EOP, Turnbull DI, Linton AL. 1978. Protective Effect of Prostaglandin [PGE2] İn Glycerol-İnduced Acute Renal Failure İn Rats. Clinical Science and Molecular Medicine, 55: 505-507.

Yared A, Kon V, Ichikawa I. 1985. Mechanism of preservation of glomerular perfusion and filtration during acute extracellular fluid volume depletion. Importance of intrarenal vasopressin- prostaglandin interaction for protecting kidneys from constrictor action of vasopressin. The Journal of Clinical Investigation.75: 1477-1487. doi:10.1172/ JCI111851

Yavuz D, Mete T, Yavuz R, Altunoğlu A. 2014. Vitamin D, Calcium and Mineral Metabolism, Extraskeletal Effects of Vitamin D and the Use of Nutritional Vitamin D in Chronic Kidney Disease. Ankara Medical Journal, 14: 162-171. doi:10.17098/amj.19812

Yilmaz M, Mert H, Irak K, Erten R, Mert N. 2018. The effect of fucoidan on the gentamicin induced nephrotoxicity in rats. Fresenius Environmental Bulletin 27: 2235-2241. 